\title{
Analysis Students' Scientific Explanation Skills Using Explanation Driven Inquiry Learning on Acid-Base Topic
}

\author{
Oktavia Sulistina ${ }^{1}{ }^{*}$, Hesti Puspitasari ${ }^{1}$, and Dedek Sukarianingsih ${ }^{1}$ \\ ${ }^{1}$ Department of Chemistry Education, Faculty of Math and Science, \\ Universitas Negeri Malang, Jl. Semarang No.5, Lowokwaru, Malang, 65145, Indonesia \\ *Email: oktavia.sulistina.fmipa@um.ac.id
}

Received: 14 March 2021; Accepted: 20 May 2021; Published: 30 June 2021

\begin{abstract}
This study analyzes students' scientific explanation skills using explanation driven inquiry (EDI) learning on acid-base topics. The method used a quasi-experimental design with a posttest-only control group design. The research sample consisted of two groups that 30 students each in EDI (experimental group) and guided inquiry (GI) (control group). The research instrument was essay questions. The EDI learning model provides better results than the guided inquiry (GI) learning model for students' scientific explanation skills. The quality of the students' scientific explanation skills reached the highest level (level 4). EDI class students were more likely to achieve it than the Gl class.
\end{abstract}

Keywords: acid-base, explanation driven inquiry, scientific explanation skills

DOI : https://doi.org/10.15575/jtk.v6i1.12495

\section{Introduction}

The progress of science in education in the $21^{\text {st }}$ century is increasing rapidly (Murti \& Madya, 2013). This is reflected in the increasing quality of human life. Various life challenges faced by humans have begun to emerge and require innovative solutions based on scientific thinking and scientific discoveries (OECD, 2016b). Students are required to master the field of content, but they are also expected to master the skills needed in the $21^{\text {st }}$ century to ensure their competitiveness in the knowledge era (Rahayu, 2017). One of the categories of skills demanded in the $21^{\text {st }}$ century is scientific literacy skills.

One aspect of scientific literacy is explaining scientific phenomena (OECD, 2015), namely scientific explanation skills. A Scientific explanation is one of the objectives of the inquiry process that leads to an understanding of a natural phenomenon and conveys that scientific literacy is explaining understanding to others (Sandoval \& Reiser, 2004; Berland \& Reiser, 2008).

A scientific explanation is an important competence to develop in learning because it can help students understand the main concepts in science (NRC, 2011). The higher the scientific explanation ability, the better students' understanding of science content (McNeil \& Krajick, 2008). Students are part of a global society who are required to understand scientific concepts and have to play a role in scientific discussions (Khun, 2010). In scientific discussions, students who have good scientific explanation skills will be able to explain scientific or chemical and technological phenomena to be useful in thinking about resolving environmental, economic, and/or social problems that occur in society (OECD, 2016b).

Scientific explanation skills are considered important, but the achievement of Indonesian 
scientific literacy as assessed by Programme for International Student Assessment (PISA) in 2015 is still in a relatively low order, (Kastberg et al., 2016). The analysis conducted by Firman (2016) related to the 2012 PISA results stated that the low achievement of Indonesian scientific literacy was due to Indonesian students still having limitations in clearly stating scientific explanations.

Research conducted by Braaten and Windschitl (2011) shows that students tend only to explain what happened when asked to explain a phenomenon. Student should also explain how and why this phenomenon occurs. The analysis and research results support the need to train and develop students scientific explanation skills in learning as supporting aspect for scientific literacy. Learning in Indonesia has not yet directed and developed students' potential towards scientific literacy, so students are not used to applying their knowledge to solve problems. This is in line with research conducted by Rahayu (2016), which states that learning implemented in Indonesia is not following the demands of the times, so it cannot facilitate students in building scientific explanations. Therefore, learning should be designed so that students can "think like a scientist" (OECD, 2016), which is a characteristic of inquiry-based learning.

One learning model that can develop students' scientific explanation is guided inquiry (GI). GI has several stages: orientation, formulating problems, formulating hypotheses, collecting data, testing hypotheses, and formulating conclusions (Sanjaya, 2011). Gl can improve students' scientific explanation skills through the learning process that departs from curiosity, looks for the course's core information, and all the activities students carry out to find a problem along with proof (Suyanti, 2010).

Using the $\mathrm{Gl}$ learning model to improve students' scientific explanation skills is not an easy job. Several researchers explained the difficulties faced in using the $\mathrm{Gl}$ learning model. Asniar's research (2016) states that the learning model can generate students' scientific explanation skills but has not produced high-level scientific explanations. The GI learning model to improve students' scientific explanation skills needs to be improved with guidance in building explanations gradually in the EDI learning model.

Explanation Driven Inquiry (EDI) is an inquirybased learning model designed to focus student activities on constructing and evaluating scientific explanation (Sandoval \& Reiser, 2004). The EDI model helps students understand higher material through a combination of the investigation process and the construction of scientific explanations (Lu et al., 2018). The stages of the EDI learning model used in this study adapt the stages of the Argument-Driven Inquiry (ADI) learning model developed by Sampson et al. (2009). The stages of the modified ADI learning model are at the argument production stage and the argumentation session. In addition, the argument production stage is modified into the scientific explanation. The production stage and the modified argumentation session stage become the discussion session stage. The EDI model stages used in this study are the task identification stage, data collection, scientific explanation production, discussion sessions, report preparation, report review, revised report, and reflective discussion.

The EDI learning model provides opportunities for students to improve writing skills, verbal communication skills, and the ability to interpret evidence and reasons scientifically (Demircioglu \& Ucar, 2015). The involvement of students in the modified EDI model stages of the Argument-Driven Inquiry (ADI) model, which emphasizes investigation activities, the process of writing scientific explanation, discussion, and review sessions, is believed to improve students' scientific explanation skills.

One of the development of scientific explanation can be done on the topic of acidbase. The acid-base topic has conceptual characteristics (Sheppard, 2006), which describes concepts and problems that are 
conceptual. Therefore, there is a need for discussion between students to explore and build the concept. In practice, learning activities on acid-base topics require the development of scientific explanation skills.

\section{Research Method}

\subsection{Study Group}

The research design used quasi-experimental with posttest only control group design (Table 1).

Table 1. Quasy Experimental Posttest Only Control Group Design

\begin{tabular}{ccc}
\hline Class & Treatment & Posttest \\
\hline EDI & $X_{1}$ & 0 \\
GI & $X_{2}$ & 0 \\
\hline
\end{tabular}

The research was conducted at one of the public high schools in Banyuwangi city with class XI natural science students. The research sample consisted of two (2) groups, namely the class that was taught by EDI (experimental group) and the class that was taught with $\mathrm{Gl}$ (control group) with a total of 30 students each. The two groups had no different initial abilities (the Independent Sample t-Test had a significance value of $0.166>0.05$ ).

\subsection{Intervention}

The experimental group and the control group were given different treatments. The experimental group was taught the EDI model. The steps for learning with the EDI model include: 1) Identification of tasks; 2) data collection; 3) production of scientific explanation; 4) discussion sessions; 5) preparation of a written investigation report; 6) report review; 7) revised report; and 8) reflective discussion (adaptation of Sampson et al., 2009). The control group was taught the $\mathrm{Gl}$ model. The $\mathrm{Gl}$ model learning steps include: 1) orientation; 2) formulating the problem; 3) formulating hypotheses; 4) collecting data; testing the hypothesis; and 5) formulate conclusions (Sanjaya, 2011).

\subsection{Research Instrument}

The research instrument was in the form of essay questions to measure students' scientific explanation skills. The scientific explanation skill test instrument consists of six valid questions and has a reliability value of 0.615 .

Scientific explanation skills were assessed according to progression evidence-based explanation (Gotwals et al., 2009). The student's scientific explanation quality category system according to progression evidence-based explanation can be seen in Table 2.

Table 2. Quality Category System of Scientific Explanation (Gotwals et al., 2009)

\begin{tabular}{cl}
\hline Category & \multicolumn{1}{c}{ Criteria } \\
\hline Level 4 & $\begin{array}{l}\text { Students build scientific } \\
\text { explanations consisting of } \\
\text { accurate and complete claims and } \\
\text { evidence and reasoning to link } \\
\text { evidence and claims. } \\
\text { Level 3 } \\
\text { Students make accurate and } \\
\text { complete claims and evidence but } \\
\text { are unable to provide reasoning } \\
\text { linking claims and evidence. }\end{array}$ \\
Level 2 & $\begin{array}{l}\text { Students make claims } \\
\text { accompanied by evidence, but the } \\
\text { evidence is incomplete / } \\
\text { inaccurate } \\
\text { Students make claims but are not } \\
\text { accompanied by evidence }\end{array}$ \\
\hline
\end{tabular}

The answers to the scientific explanation test were examined separately by two interrater. First, the assessment results were tested using the Kappa test and a coding agreement percentage was obtained of 0.825 , which was a very high category. The results of the students' scientific explanation level are then converted into a score. Second, Statistical analysis used the Independent Sample t-Test at the 0.05 significance level to determine the differences in scientific explanation skills between students taught with EDI and students taught with $\mathrm{Gl}$.

\section{Result and Discussion}

Scientific explanation skill data were obtained from students' answers to six essay questions on acid-base material. A total of 360 student answers were then further categorized using progression evidence-based explanation to 
find out the quality of the scientific explanation, which consisted of four categories, namely level 1 , level 2 , level 3 , and level 4 . The histogram of the distribution of the quality of scientific explanation for students in EDI and GI classes can be seen in Figure 1 . In addition, a summary of the values of the students' scientific explanation skills for EDI and GI class students is presented in Table 3.

\section{Students' Scientific Explanation Quality}

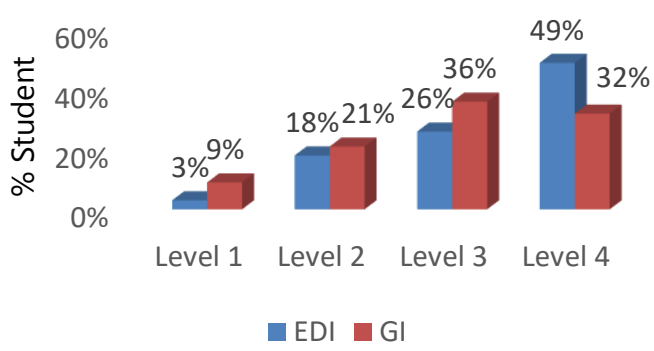

Figure 1. Students' Scientific Explanation Quality of EDI and GI classes

The mean value of EDI class students 'scientific explanation skills $\left(x^{-}=79.53\right)$ was higher than the mean value of $\mathrm{Gl}$ class students' scientific explanation skills $\left(\mathrm{x}^{-}=\right.$ 71.73). This is presumably because the EDI learning model better affects scientific explanation skills than the Gl learning model.
Proving this hypothesis requires statistical analysis using the Independent Sample t-Test.

The hypothesis test results for the students' scientific explanation skills in the EDI class and the Gl class showed that the significance value was 0.011 . This value meets the criteria of Sig. $<0.05$, so it can be concluded that there are differences in students' scientific explanation skills using the EDI learning model with students who are taught using the GI learning model. The average value of EDI class students' scientific explanation skills is higher than that of the Gl class, so it can be stated that the EDI learning model provides better results than the GI learning model. The learning process for students who are taught with EDI explicitly trains students in constructing valid scientific explanations. The EDI learning model in this study was adapted from the ADI learning model. In the EDI learning model, there is a scientific explanation production stage, Student Worksheet at the scientific explanation production stage facilitates students in constructing scientific explanations in stages. An example of Student Worksheet samples during the production stage of scientific explanation on the sub-topic for estimating $\mathrm{pH}$ using the acid-base indicator can be seen in Figure 2.

Table 3. Summary of the Scientific Explanation Skill Scores of EDI and GI Class Students

\begin{tabular}{cccccc}
\hline Group & $\boldsymbol{\Sigma}$ of student & Lowest Score & Highest Score & Average & SD \\
\hline EDI & 30 & 58 & 100 & 79.53 & 11.107 \\
GI & 30 & 54 & 96 & 71.73 & 11.870 \\
\hline
\end{tabular}

Scientific explanation skills require not only good cognitive abilities but also communication skills. Learning with the EDI model includes discussion session stages. Students are trained to deliver more accurate scientific explanations when students explain the result of data analysis and concepts obtained directly. This is supported by Sampson et al. (2009), which states that the discussion session is designed for students to critically review the product (claims, evidence, and reasoning), process (method) and context (theoretical basis) of an inquiry.
The peer-review stage also supports an increase in the quality of the scientific explanations. Through this stage, students are encouraged to develop and use appropriate standards in assessing quality scientific explanations. Lange (2011) states that peer review can be a strong motivator for students to improve the quality of writing and learn about how to write a better scientific explanation. So this stage can improve scientific explanation skills because students can not only analyze other students' scientific explanations, but are also motivated to improve the quality of the scientific 
explanations (Marhamah et al., 2017). This is supported by research by Akkus (2007) which shows that emphasizing collaboration on scientific explanations and peer reviews can significantly improve the quality of scientific explanations.

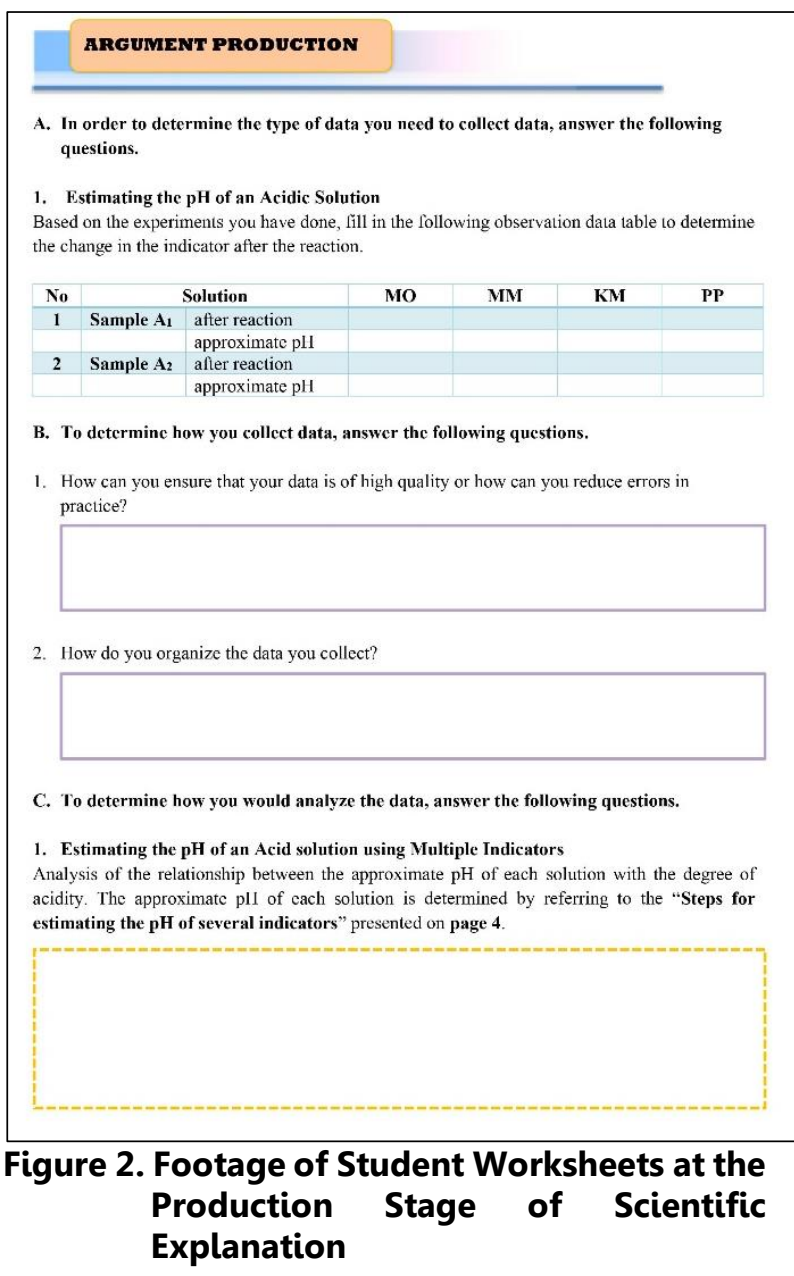

The learning experience of students who are taught with $\mathrm{Gl}$ is different from students who are taught with EDI. Students who are taught with Gl are only trained in building scientific explanations at the hypothesis testing stage. During testing the hypothesis, the teacher provides implicit guidance to students to construct a scientific explanation consisting of claims, evidence, and reasoning. The student's scientific explanation construction results are then conveyed in front of the class to determine which scientific explanation is considered following the data or information obtained based on data collection. In the GI learning model, there are no steps to emphasize and focus on student involvement in constructing scientific explanations, such as the production stage of scientific explanation, scientific explanation discussion sessions, and peer reviews in the stages of the EDI learning model. The absence of these stages causes a lack of student intensity in building scientific explanations so that the students' scientific explanation skills who are taught with $\mathrm{Gl}$ are lower.

\section{Conclusion}

Based on the results of the research and discussion that has been described, it can be concluded that the EDI learning model provides better results than the Gl learning model for students' scientific explanation skills. When viewed from the quality of the students' scientific explanation skills who reached the highest level (level 4), EDI class students were more likely to achieve it than the GI class. The suggestion given to the next researcher is that it can be studied the effect of the EDI learning model on other materials that have almost the same characteristics.

\section{References}

Akkus, R., Gunel, M., \& Hand, B. (2007). Comparing an inquiry-based approach known as the science writing heuristic to traditional science teaching practices: are there differences?. International Journal of Science Education, 29(14), 1745-1765. https://doi.org/10.1080/09500690601 075629.

Asniar, A. (2016). Profil penalaran ilmiah dan kemampuan argumentasi mahasiswa sains dan non sains. Jurnal Penelitian dan Pembelajaran IPA, 2(1), 30-41. http://dx.doi.org/10.30870/jppi.v2i1.4 28.
Berland, L. K., \& Reiser, B. (2008). Making sense of argumentation and explanation. Science Education, 3(1), 26-55. https://doi.org/10.1002/sce.20286.


Braaten, M., \& Windschitl, M. (2011). Working toward a stronger conceptualization of scientific explanation for science education. Science Education, 95(4), 639-669.

https://doi.org/10.1002/sce.20449

Demircioglu, T., \& Ucar, S. (2015). Investigating the effect of argument driven inquiry in laboratory instruction. Journal of Educational Sciences, 12(1), 267-283. https://doi.org/10.12738/estp.2015.1. 2324

Firman, H. (2016). Diagnosing weaknesses of indonesian students' learning. In: thien L. M., Razak N. A., Keeves J. P., Darmawan I. G. N. (eds) what can pisa 2012 data tell us? Rotterdam: SensePublishers. https://doi.org/10.1007/978-94-6300468-8_5

Gotwals, A. W., Songer. N. B., \& Bullard, L. (2009). Assessing student progressing abilities to construct scientific explanation. Paper presented at the Learning Progression in Science (LeaPS) Conference, June 2009. lowa City, IA.

Kastberg, D., Chan, J. Y., Murray, G., \& Gozales, P. (2016). Performance of US 15 yearsold student science, reading, and mathematic literacy in an international context. Wangsington DC: US Departement of Education.

Lange, K. (2011). Scientific explanations peer feedback or teacher feedback. Thesis, Arizona State University. https://repository.asu.edu/attachment s/56918/content/Lange_asu_0010N_1 0872.pdf

Marhamah, O. S., Nurlaelah, I., \& Setiawati, I. (2017). Penerapan model argument driven inquiry (ADI) dalam meningkatkan kemampuan berargumentasi siswa pada konsep pencemaran lingkungan di kelas $X$
SMA Negeri Ciawigebang. Quagga, 9(2), 46-54. https://doi.org/10.25134/quagga.v9i0 2.747

McNeil, K. L., \& Krajcik, J. (2008). Scientific explanation: Characterizing and evaluating the effects of teachers' instructional practices on student learning. Journal of Research in Science Teaching, 45(1), 53-78. https://doi.org/10.1002/tea.20201

Murti, K. E. \& Madya, E. (2013). Pendidikan abad 21 dan implementasi pada pembelajaran di Sekolah Menengah Kejuruan (SMK) untuk paket keahlian desain interior. (http://p4tksbjogja.com/arsip/images/Wl/Pendidika n\%20Abad\%2021\%20dan\%20Implem entasinya.Interior.pdf), accessed 7 April 2020.

National Research Council (NRC). (2011). A framework for $K-12$ science education: Practices, crosscutting concepts, and core ideas. Washington DC: The National Academic Press.

Organization for Economic co-Operation and Development (OECD). (2015). PISA 2015 Draft Mathematics Framework. New York: Columbia University.

Organization for Economic co-Operation and Development (OECD). (2016a). PISA 2015: PISA Result in Focus. (htpps://www.oecd.org/pisa-2015result-in-focus.pdf), accessed 12 October 2018.

Organization for Economic co-Operation and Development (OECD). (2016b). PISA 2015 assesment and analitical framework: Science, reading, mathematic and financial literacy. Paris: OECD Publishing.

Rahayu, S. (2014). Menuju masyarakat beliterasi sains: Harapan dan tantangan Kurikulum 2013. Paper presented at the Seminar Nasional 
Kimia dan Pembelajarannya (SNKP), Malang: Universitas Negeri Malang.

Rahayu, S. (2016). Mengembangkan keterampilan tinggi siswa melalui pembelajaran kimia berkonteks sosioscientific issue (SSI) and nature of sience (NOS). Paper presented at the Seminar Nasional Kimia dan Pembelajarannya (SNKP), Malang: Universitas Negeri Malang.

Rahayu, S. (2017). Promoting the $21^{\text {st }}$ century scientific literacy skill trough innovative chemistry intruction. AIP Conference Proceedings, 1911(1), 1180.

https://doi.org/10.1063/1.5016018.

Sampson, V., Groms, J., \& Walker, J. (2009). Argument-driven inquiry to promote learning during laboratory activities. The Science Teacher, 76(8), 425-472.

Sandoval, W. A., \& Reiser, B. J. (2004). Explanation-Driven Inquiry: Integration conceptual and epistemic scaffolds for scientific inquiry. Science Education, 88 (3), 345-372. https://doi.org/10.1002/sce.10130.

Sanjaya, W. (2011). Strategi Pembelajaran Berorientasi Standar Proses Pendidikan. Jakarta: Kencana Media Group.

Lu, S., Bi, H., \& Liu, X. (2018). The effect of explanation - driven - inquiry on students' conceptual understanding of redox. International Journal of Science Education. 15(40), 1857-1873. https://doi.org/10.1080/09500693.20 18.1513670.

Sheppard, K. (2006). High school students' understanding of titrations and related acid-base phenomena. Chemistry Education Research and Practice, Vol 7(1), 32-45. https://doi.org/10.1039/B5RP90014J
Suyanti, R. D. (2010). Strategi pembelajaran kimia. Yogyakarta: Gramedia. 